\title{
Water Impacts of a Low-Carbon Electric Power Future: Assessment Methodology and Status
}

\author{
Haibo Zhai • Edward S. Rubin
}

Published online: 10 January 2015

(C) Springer International Publishing AG 2015

\begin{abstract}
Water is an integral element of energy production. Future US energy production will increasingly be driven by the need to mitigate climate change, posing complex water challenges. The water impacts of electricity generation in a carbon-constrained future have been a subject of active research. This paper reviews technologies and regulatory policy options for low-carbon electricity generation, including systems that use fossil fuels with carbon capture and storage, renewables such as wind, solar, and biomass, and nuclear energy. We also review cooling technologies in support of thermoelectric power generation, report and discuss current assessment methods and results on water use for low-carbon energy production, and identify adaptive approaches that could reinforce resilience for low-carbon electricity generation. Some recommendations are made for future research.
\end{abstract}

Keywords Future $\cdot$ Low-carbon $\cdot$ Electricity generation · Cooling $\cdot$ Water use $\cdot$ Impacts $\cdot$ Coal $\cdot$ Natural gas $\cdot$ Carbon capture and storage $\cdot$ Renewable energy $\cdot$ Nuclear .

Regulations $\cdot$ Policies

\section{Introduction}

Water is an integral element of energy production. Along with US population and economic growth, the demand for energy, especially electricity, continues to grow; this, in turn, may increase water use for energy production. Future US

This article is part of the Topical Collection on Energy-Water Nexus

H. Zhai $(\bowtie) \cdot$ E. S. Rubin

Department of Engineering and Public Policy, Carnegie Mellon

University, Pittsburgh, PA 15213, USA

e-mail: hbzhai@cmu.edu electricity generation will increasingly be driven by the need to mitigate climate change, posing complex water challenges for the electric power industry, water resource management, and policy or decision makers. The challenges may also vary by location. Thus, the water impacts of electricity generation towards a low-carbon energy future have been receiving growing attention. Low-carbon resources considered for electricity generation include fossil fuel with carbon capture and storage (CCS), renewables such as wind, solar and biomass, and nuclear energy. The overall objective of this paper was to review and discuss the state-of-the-art assessment methodology and results on this subject. Specifically, we review technologies and regulatory policy options for low-carbon electricity generation as well as cooling technologies employed for thermoelectric power plants, report and discuss current assessment methods and results on water use for energy production using low-carbon resources, and identify adaptive approaches that help secure water use for electricity generation in a carbon-constrained world.

\section{Technologies, Regulations, and Policies for Low-Carbon Electricity Generation}

A transition from carbon-intensive fossil fuels to low-carbon resources and technologies for electricity generation has increasingly been considered as one of the most important approaches for climate change mitigation. In this transition, CCS could play a key role in deeply cutting carbon dioxide $\left(\mathrm{CO}_{2}\right)$ emissions from fossil-fuel-fired power plants. However, the CCS implementation would significantly increase plant water use due to the large amount of additional cooling water required for the capture process [1]. Driven by low gas prices and new supplies from shale gas production, a shift from coal to natural gas for electricity generation may facilitate the transition to a low-carbon energy future. Increasing the use 
of renewables and nuclear power will help to decarbonize the electric power sector $[2 \bullet, 3]$. The generation mix of a carbonconstrained energy future will be determined largely by resource availability and cost of electricity generation, and be shaped by low-carbon regulations and policies. Table 1 summarizes the costs of major power generation systems $[4,5]$.

Regulations and policies are drivers needed to limit $\mathrm{CO}_{2}$ emissions from the power sector and to incentivize innovations and technological changes, as well as market establishment for low-carbon energy technologies. In September 2013, the US Environmental Protection Agency (EPA) issued a new proposal that sets up separate performance standards for limiting $\mathrm{CO}_{2}$ emissions from new coal- and gas-fired electric generating units (EGUs) [6]. Compliance with the current proposal would require approximately $40-50 \% \mathrm{CO}_{2}$ capture for new coal-fired EGUs, varying with power-plant designs [7]. Once these new source performance standards come into effect, Section 111(d) of the Clean Air Act requires the EPA to establish carbon pollution standards for existing power plants.

Table 1 Cost of electricity and water use for different power generation systems

\begin{tabular}{|c|c|c|c|c|}
\hline \multirow[t]{2}{*}{ Plant type } & \multirow[t]{2}{*}{$\begin{array}{l}\text { Capacity } \\
\text { factor } \\
(\%)^{\mathrm{a}}\end{array}$} & \multirow[t]{2}{*}{$\begin{array}{l}\text { Average } \\
\text { cost of } \\
\text { electricity } \\
\text { generation } \\
(\$ / M W h)^{a}\end{array}$} & \multicolumn{2}{|c|}{$\begin{array}{l}\text { Water use based on wet } \\
\text { cooling } \\
\text { tower when applicable } \\
\text { (gallon/MWh) }^{\mathrm{b}}\end{array}$} \\
\hline & & & $\begin{array}{l}\text { Water } \\
\text { withdrawal }\end{array}$ & $\begin{array}{l}\text { Water } \\
\text { consumption }\end{array}$ \\
\hline \multicolumn{5}{|c|}{ Dispatchable technologies } \\
\hline SC PC & $85^{\mathrm{c}}$ & $58.9^{\mathrm{c}}$ & $582-670$ & $445-594$ \\
\hline SC PC-CCS & $85^{\mathrm{c}}$ & $106.5^{\mathrm{c}}$ & $1,098-1,157$ & $815-907$ \\
\hline IGCC & $80^{\mathrm{c}}$ & $74.0-81.3^{\mathrm{c}}$ & $358-605$ & $318-439$ \\
\hline IGCC-CCS & $80^{\mathrm{c}}$ & $105.6-119.4^{\mathrm{c}}$ & $479-742$ & $522-604$ \\
\hline NGCC & 87 & 64.4 & $150-283$ & $130-300$ \\
\hline $\begin{array}{c}\text { NGCC- } \\
\text { CCS }\end{array}$ & 87 & 91.3 & $487-544$ & $378-407$ \\
\hline Nuclear & 90 & 96.1 & $800-2,600$ & $581-845$ \\
\hline Geothermal & 92 & 47.9 & 5-361 & 5-361 \\
\hline Biomass & 83 & 102.6 & $500-1,460$ & $480-965$ \\
\hline \multicolumn{5}{|c|}{ Non-dispatchable technologies } \\
\hline Wind & 35 & 80.3 & 0 & 0 \\
\hline $\begin{array}{l}\text { Wind- } \\
\text { offshore }\end{array}$ & 37 & 204.1 & 0 & 0 \\
\hline Solar PV & 25 & 130.0 & $0-5$ & $0-5$ \\
\hline $\begin{array}{l}\text { Solar } \\
\text { thermal }\end{array}$ & 20 & 243.1 & $725-1,109$ & $725-1,109$ \\
\hline Hydro & 53 & 84.5 & $1,425-18,000$ & $1,425-18,000$ \\
\hline
\end{tabular}

$S C P C$ supercritical pulverized coal, CCS carbon capture and storage, $I G C C$ integrated gasification combined cycle, $N G C C$ natural gas combined cycle, $P V$ photovoltaic

${ }^{\text {a }}$ Source of data: US Energy Information Administration [4]

${ }^{\mathrm{b}}$ Source of data: Macknick et al. [12•]

${ }^{\mathrm{c}}$ Source of data: National Energy Technology Laboratory [5]
Thus, the EPA proposed a flexible Clean Power Plan that sets up state-specific emission goals in order to reduce nationwide carbon pollution from the power sector by $30 \%$, from 2005 levels, in 2030 [8]. States have the flexibility to choose how to meet the goals, especially through programs that encourage heat rate improvement for fossil fuel power plants, increased utilization of natural gas combined cycle (NGCC) plants, renewable energy, and energy efficiency. In addition, other regulatory and policy options have been considered to promote low-carbon energy production, including $\mathrm{CO}_{2}$ emission budgets, $\mathrm{CO}_{2}$ emission prices or taxes, cap-and-trade programs, or the combination of the multiple options.

\section{Cooling Technologies for Thermoelectric Power Plants}

Water is used in thermoelectric power plants, mainly for the purpose of cooling. In contrast, in photovoltaic (PV) and wind power plants, water is used occasionally for cleaning or washing, which is negligible. In general, cooling technologies can be classified into two types: wet and dry cooling, which use water and air, respectively, as the cooling fluid to dissipate exhaust heat. The combination of wet and dry cooling is called a 'hybrid cooling system'. Wet cooling technologies mainly include once-through cooling systems and closed-loop cooling ponds and towers, whereas dry cooling technologies include air-cooled condensers. Once-through cooling systems withdraw a large amount of cool water from a source via intake structures and then discharge the heated water directly back into the source. Once-through cooling systems produce adverse environmental impacts at both the intake and the outlet, but are relatively inexpensive compared with closedloop cooling systems. In comparison between wet cooling towers and ponds, cooling ponds require a larger amount of land but less operating power and capital costs [9]. Different from wet cooling systems, dry cooling systems have no direct water use, but require more operating power, space, and capital costs than those of wet towers [10].

The EPA issued regulations on cooling intake structures under Section 316(b) of the Clean Water Act to minimize adverse environmental impacts [11]. The regulations promote the switch from once-through cooling to wet cooling towers or ponds since they are considered as 'best technology available' for meeting the requirements. Among various power plants, coal plants with CCS and concentrating solar power (CSP) plants using wet towers have the highest water consumption intensities, whereas non-thermal renewable plants such as PV and wind have the lowest water consumption. Nuclear plants with once-through cooling have the highest water withdrawal intensities, whereas non-thermal renewable energy technologies have the smallest values. Table 1 also presents water-use factors for different generation systems using wet cooling towers where applicable. Compared with wet cooling, the 
water use for dry cooling is negligible. More details of plant water use are available in the review by Macknick et al. [12•].

\section{Energy-Water Assessment Approaches}

The water demand for regional low-carbon energy production is often estimated as the product of regional electricity generation projections multiplied by power-plant water-use factors. Thus, we first review current approaches that are employed to estimate plant-level water-use factors and regional electricity generation for alternative low-carbon energy futures.

\section{Plant-Level Water-Use Factors}

Three major approaches are reported to estimate plant wateruse factors in gallons per megawatt-hour, including utility survey, top-down approach, and bottom-up approach.

- Survey forms Survey forms collected by the US Energy Information Administration (EIA) from individual utilities, such as EIA-767, EIA-860, and EIA-923, are used to derive water-use factors $[3,13 \cdot$, 14]. However, this approach is based on the data of current generation systems and does not account for the differences between the current and future generation fleets.

- Top-down approach Average water-use factors are estimated based on the total water use divided by the total power generation in an energy-generating region. The US Geological Survey reports total generation and water use for thermoelectric plants at the county level by water type (fresh vs. saline), source (surface water vs. groundwater), and cooling technology [9]. However, no distinction is made for the type of plants using the same cooling technology. The water-use factors used for regional assessments often remain constant.

- Bottom-up approach Water-use models are developed based on fundamental mass and energy balances for thermoelectric power plants [1]. Thus, this kind of water-use model can explain variability by power plant and cooling system designs in plant water use [1]. Once probabilistic distribution functions are assigned to input variables under uncertainty, stochastic simulation can be carried out to yield the probabilistic range of plant water use and estimate the likelihood of a specific outcome.

Macknick et al. conducted a review that summarizes plantlevel water-use factors available from the literature for a range of electricity generation and cooling systems [12•]. This review reveals that currently reported water-use factors are inconsistent, and have high uncertainties. The water-use factors adopted in the literature are estimated mainly on an annual national average basis without quantification of uncertainties.
The water-use estimates derived from survey data cannot sufficiently account for the variability by either location or season, which can exceed $15 \%[2 \bullet, 12 \bullet]$. Furthermore, the effects on water-use factors of improving thermal plant efficiency over time are not considered in many energy-water studies, which could lead to biases in regional water demand estimates for future scenarios.

\section{Energy Modeling for Alternative Low-Carbon Scenarios}

Energy modeling tools have been employed widely to forecast regional electricity generation and the generation mix under alternative low-carbon technology, climate, regulation, and policy scenarios. The current major tools used for energywater assessments include the US EIA's National Energy Modeling System (NEMS), the National Renewable Energy Laboratory's Regional Energy Deployment System (ReEDS), the Joint Global Change Research Institute's Global Change Assessment Model (GCAM), and the Energy Technology Systems Analysis Program's MARKet ALlocation (MARKAL) model, briefly described as follows:

- $\quad N E M S$ is a regional, energy-economy modeling system of the US with a projection horizon of approximately 25 years into the future. It is used to project the complex interactions of the US energy system and its response to a range of alternative energy policies and different assumptions [15].

- ReEDS is a long-term capacity-expansion and dispatch model for the deployment of electric power generation technologies and transmission infrastructure throughout the contiguous US in 2-year increments to the year 2050 $[2 \bullet, 16 \bullet]$. The model can be applied to evaluate numerous key issues related to renewable energy, such as regional quality of renewable resources, seasonal and diurnal load, and generation profiles $[2 \bullet, 16 \bullet]$.

- GCAM is an integrated assessment model designed for long-term analysis of energy, agriculture and land use, and climate, and offers projections of future energy supply and demand and water use for the electric power sector [17, 18]. GCAM can be used to evaluate climate change mitigation policies, including carbon taxes and trading, regulations and accelerated deployment of energy technology, as well as emission targets from various sources with a simulation period from 1990 to 2095.

- MARKAL is a data-driven, energy systems/economic optimization model that determines the least cost set of technologies over time to meet the specified demands under various user-defined constraints, including resource supplies, energy conversion technologies, and end-use demands and associated technologies [19]. EPA has developed a nine-region MARKAL model that can be applied to explore future energy scenarios [19]. 
It is difficult to make predictions about the future. The projections made by these tools should be considered to be statements of what might happen for the given methods, assumptions, and inputs. Thus, the model validation for either business-as-usual (BAU) or alternative low-carbon energy scenarios is widely missing or barely discussed in literature. Projections of energy future are basically presented in deterministic form rather than probabilistic form.

\section{Water Impacts of Low-Carbon Electricity Generation}

A variety of regulatory and policy strategies have been proposed or evaluated to help promote the use of low-carbon energy resources and technologies. The enactment of the US EPA's proposed $\mathrm{CO}_{2}$ emission standards would produce substantial impacts on the electric power sector. The implementation of partial CCS to comply with the proposed standards will increase plant-level water use by approximately 20-50\% in coal-fired plants, varying with power plant and CCS designs [20 ]. In contrast, new NGCC plants are able to meet the emission standards without any need for carbon capture. As a result, the levelized cost of electricity (LCOE) of a new baseload NGCC plant is $20 \%$ less than that of a coal-fired plant, but is highly dependent on the gas price; water use of the NGCC plant is approximately $70 \%$ less than that of the regulated coal-fired plant [20•]. In the electric power sector, the proposed emission standards may also facilitate the shift from coal to natural gas as a bridge to a lower-carbon energy future, resulting in less water use.

A variety of low-carbon fuels and technologies for electricity generation can produce different impacts on regional water resources. Regional water demand is also highly affected by the share of cooling technologies in the generation fleet. As summarized in Table 2, we review and discuss recent studies that investigate various combinations of technological pathways and policy strategies towards a low-carbon energy future for the period from 2030 to 2055 , and evaluate their national and/or regional water impacts.

- CCS retrofit and carbon price Chandel et al. evaluated four low-carbon scenarios that explore different combinations of carbon price and CCS retrofit [13•]. Among these, the low-price scenarios start with a carbon price of $\$ 15 /$ tonne, whereas the high-price scenarios start with a carbon price of $\$ 25 /$ tonne. Nuclear power would increase by 34 $49 \%$ for the low-price scenarios and 95-98\% for the high-price scenarios. Higher carbon prices than $\$ 50 /$ tonne of $\mathrm{CO}_{2}$ would drive the deployment of CCS to reduce $\mathrm{CO}_{2}$ emissions from coal plants and increase freshwater consumption. The low-carbon policies would decrease freshwater withdrawals by $2-14 \%$ compared with those of the BAU scenario without climate polices. Freshwater consumption of all the scenarios would increase by 24 $42 \%$ from 2010 to 2030 , mainly because of the shift from once-through to closed-loop cooling systems. If wind and PV plants are installed to replace conventional coal plants, water withdrawals and consumption would decrease by $18-23 \%$ and $14-21 \%$, respectively.

Chandel et al. further illustrated that the water impacts of low-carbon electricity generation would vary by location [13•]. By 2030, the low-carbon climate policies would lead to remarkable reductions in water withdrawals from 5 to $33 \%$ in the ECAR, MAIN, NY, and NRCC/NE regions (defined by the North American Electric Reliability Corporation), but increases in water withdrawals by $10 \%$ and $13-44 \%$ in the FRCC/FL and RM regions, respectively. Most pronounced increases in water consumption are projected to take place in the South and East, including Florida, New England, New York, Texas, and the Mid-Atlantic, which result from the collective effects of multiple factors: electricity generation increase, generation mix change, and CCS retrofit for coal plants.

- Improved fossil fuel and renewable energy technologies Tidwell et al. estimated future water demands for electricity generation based on the EIA's energy projections for multiple alternative cases, including the Reference Case, Low Fossil Technology Cost Case, and Low Renewable Technology Cost Case, and further evaluated water availability based on the water supply data collected at the sixdigit hydrologic unit code level [21•]. The major difference between the alternative cases is the mix profile characterized by fuel and technology types. Their assessment of water availability indicates that, for the Reference case, $19 \%$ of new electric power generation between 2007 and 2035 is likely to be sited in basins with limited surface water or groundwater availability. In contrast, $17 \%$ of new thermoelectric power generation projected in the Low Fossil Technology Cost scenario is likely to be sited in regions with limited water availability, whereas that of the Low Renewable Technology Cost scenario is $9.5 \%$; the retirement of once-through cooling systems and the deployment of wet closed-loop cooling systems will collectively decrease water withdrawals but increase water consumption, and significant portions of the Great Plains, Southwest, West, and Florida are identified to be regions with limited water availability for future development.

- Carbon budget with or without low-carbon technology preference Macknick et al. and Clemmer et al. evaluated the national and regional water-use impacts of low-carbon energy production under the constraints of an economywide carbon budget (170-Gt $\left.\mathrm{CO}_{2} \mathrm{eq}\right)$ and generation technology preference illustrated in Table $2[2 \bullet, 16 \bullet]$. In the BAU scenario, natural gas is expected to become the 
Table 2 Water impacts of alternative low-carbon electricity generation pathways

\begin{tabular}{|c|c|c|c|c|c|}
\hline $\begin{array}{l}\text { Study, } \\
\text { year }\end{array}$ & $\begin{array}{l}\text { Energy modeling } \\
\text { tool }\end{array}$ & $\begin{array}{l}\text { Time } \\
\text { horizon }\end{array}$ & $\begin{array}{l}\text { Geographic } \\
\text { modeling } \\
\text { resolution }\end{array}$ & $\begin{array}{l}\text { Low-carbon electric power } \\
\text { generation scenarios }\end{array}$ & National or regional water impacts \\
\hline
\end{tabular}

\begin{tabular}{|c|c|c|c|c|}
\hline $\begin{array}{l}\text { Chandel } \\
\text { et al. } \\
{[13 \bullet]} \\
2011\end{array}$ & $\begin{array}{l}\text { Modified NEMS } \\
\text { with an added } \\
\text { module for } \\
\text { CCS }\end{array}$ & 2030 & $\begin{array}{l}\text { North American } \\
\text { Reliability } \\
\text { Corporation } \\
\text { regions }\end{array}$ & $\begin{array}{l}\text { - Low-carbon allowance price, no } \\
\text { CCS retrofits allowed } \\
\text { - Low-carbon allowance price, } \\
\text { CCS retrofits allowed } \\
\text { - High-carbon allowance price, no } \\
\text { CCS retrofits allowed } \\
\text { - High-carbon allowance price, } \\
\text { CCS retrofits allowed }\end{array}$ \\
\hline $\begin{array}{l}\text { Tidwell } \\
\text { et al. } \\
{[21 \bullet]}\end{array}$ & EIA's AEO2011 & 2035 & $\begin{array}{l}\text { Hydrologic unit } \\
\text { code }\end{array}$ & $\begin{array}{l}\text { - Low fossil technology cost case } \\
\text { - Low renewable technology cost } \\
\text { case }\end{array}$ \\
\hline
\end{tabular}

- Freshwater withdrawals of low-carbon scenarios would decrease by $2-14 \%$ compared with those of the business-as-usual scenario

- Freshwater consumption of low-carbon scenarios would increase by $24-42 \%$ between 2010 and 2030

- The addition of CCS to coal plants under the constraint of carbon prices more than $\$ 50 /$ ton of $\mathrm{CO}_{2}$ would increase freshwater water consumption

- The water impacts of low-carbon policies vary by location

- $17 \%$ of new thermoelectric power generation projected in the low fossil technology cost case is likely to be sited at regions with limited water availability. In contrast, that is $9.5 \%$ for the low renewable technology cost case

- The identified regions with limited water availability are significant portions of the Florida, Great Plains, Southwest, and West.

Macknick ReEDS
et al.
$[2 \bullet]$
2012
Hydrologic unit code
- Carbon budget, no technology targets
- Carbon budget with technology preference on coal-CCS and nuclear

- Carbon budget with technology preference on efficiency improvement and renewable energy

- The phase-out of conventional coal plants and the increased share of NGCC plants would decrease the national water withdrawals

- High penetration of renewable energy in the future electric power sector would significantly decrease national water withdrawals by up to $97 \%$

- The national water consumption for power generation under the carbon constraints may decrease by 55 $85 \%$, highly dependent on the share of renewable energy. However, the low-carbon scenario heavily dependent on coal-CCS and nuclear plants is expected to have a higher level of national water consumption in 2050 than in 2010

- Regional trends in water consumption change with generation pathways. Substantial deployment of nuclear facilities and coal plants with CCS will increase consumptive water use in the Mid-Atlantic, Great Lakes, Central, Southeastern, and Southwestern regions of the country. Some renewable energy technologies such as CSP solar power and geothermal energy systems can lead to high water consumption in arid Western states, which depends on the grid share

Clemmer ReEDS
et al.
$[16 \cdot]$
2013
Hydrologic unit code - Carbon budget, no technology
preference

- Carbon budget with technology preference on coal-CCS and nuclear

- Carbon budget with technology preference on efficiency improvement and renewable energy

$\begin{array}{cc}\text { Webster } & \text { Generation } \\ \text { et al. } & \text { Expansion } \\ {[23 \cdot],} & \text { Model }\end{array}$

2050
Electric
Reliability
Council of

- $\mathrm{CO}_{2}$ emission constraints

- Water withdrawal constraints
- Among several low-carbon scenarios, the heavy dependence on CCS and nuclear technologies for low-carbon electricity generation will increase national water consumption by $21.7 \%$ than the 2010 level

- Aggressive penetration of renewable energy plus ambitious reductions in energy demand via efficiency improvement would significantly reduce national water use by $85 \%$ in 2050 compared with the 2010 level.

- To achieve the $75 \%$ emission reduction, most of the coal capacity is to be replaced by nuclear capacity and, in turn, would increase regional water withdrawals by $64 \%$

- Constraining $\mathrm{CO}_{2}$ emissions and water withdrawals would result in a very different generation mix, which would nearly double the NGCC capacity, 
Table 2 (continued)

\begin{tabular}{|c|c|c|c|c|c|}
\hline $\begin{array}{l}\text { Study, } \\
\text { year }\end{array}$ & $\begin{array}{l}\text { Energy modeling } \\
\text { tool }\end{array}$ & $\begin{array}{l}\text { Time } \\
\text { horizon }\end{array}$ & $\begin{array}{l}\text { Geographic } \\
\text { modeling } \\
\text { resolution }\end{array}$ & $\begin{array}{l}\text { Low-carbon electric power } \\
\text { generation scenarios }\end{array}$ & National or regional water impacts \\
\hline \multirow{3}{*}{$\begin{array}{l}\text { Cameron } \\
\text { et al. } \\
{[24 \cdot]} \\
2014\end{array}$} & \multirow{3}{*}{ MARKAL } & \multirow{3}{*}{2055} & \multirow{3}{*}{$\begin{array}{l}\text { EPA's defined } \\
\text { nine regions }\end{array}$} & \multirow{3}{*}{$\begin{array}{l}\text { - Three levels of reductions in } \\
\text { energy system-wide } \mathrm{CO}_{2} \text { emis- } \\
\text { sions }\end{array}$} & $\begin{array}{l}\text { decrease the nuclear capacity by } 40 \% \text {, and require } \\
\text { more dry or hybrid cooling in comparison with the } \\
\text { base-case. }\end{array}$ \\
\hline & & & & & $\begin{array}{l}\text { - By } 2055, \mathrm{CO}_{2} \text { emission constraints would reduce the } \\
\text { national water withdrawals by } 31-46 \% \text { in } \\
\text { comparison with that of the base-case in the electric } \\
\text { power sector }\end{array}$ \\
\hline & & & & & $\begin{array}{l}\text { By } 2055 \text {, the national water consumption for the } \\
50 \% \text { emission reduction scenario would increase } \\
\text { by } 42 \% \text { compared with that of the base-case, } \\
\text { mainly because of the increased use of recirculating } \\
\text { cooling, nuclear power plant, and NGCC-CCS }\end{array}$ \\
\hline
\end{tabular}

NEMS National Energy Modeling System, CCS carbon capture and storage, EIA Energy Information Administration, AEO2011 Annual Energy Outlook 2011, ReEDS Regional Energy Deployment System, MARKAL MARKet Allocation, EPA Environmental Protection Agency, $C_{2}$ carbon dioxide, $N G C C$ natural gas combined cycle, CSP concentrating solar power

major resource for future electricity generation. Conventional coal plants will be largely phased out by 2030 under the carbon constraints; wind and solar power is expected to have the largest growth and dominate future national generation, whereas natural gas will play a significant intermediary role.

The national water withdrawals of the BAU scenario will decrease by $26.6 \%$ in 2030 and by $80.7 \%$ in 2050 compared with those of 2010. High penetration of renewable energy would further significantly decrease national water withdrawals by $97 \%$. These national trends are mainly determined by the retirement of once-through cooling systems and the deployment of closed-loop cooling for new power plants, although coal-CCS plants and nuclear power plants use more water than other generation technologies. Under the carbon constraints, the phase-out of conventional coal plants and the increased share of NGCC plants make further contributions to the reductions in national water withdrawals. The high penetration of renewable energy will accelerate the water reduction pace. In spite of significant national water withdrawal reductions, some Western regions may experience increases in freshwater withdrawals because of increased energy demand plus the retirement of once-through coastal facilities. Parts of Texas and Arizona would have substantial increases in water withdrawals because more coal plants with CCS and nuclear plants would be installed in these regions.

Relative differences in water withdrawal and consumption factors for various power generation and cooling technologies lead to the difference in varying trends for national water consumption versus withdrawals [2•]. In the BAU case, the national water consumption would increase slightly by $0.6 \%$ in 2030 and then decrease by $34.2 \%$ in 2050 compared with the 2010 level. The national water consumption may decrease by $55-85 \%$ under the carbon constraints, highly dependent on the share of renewable energy in the future fleet. However, the low-carbon scenario heavily dependent on the deployment of coal-CCS and nuclear plants from 2030 to 2050 is expected to increase national water consumption by $21.7 \%$ compared with the 2010 level. Aggressive penetration of renewable energy plus ambitious reductions in energy demand would significantly reduce national water use by $85 \%$ in 2050 compared with the 2010 level. Arent et al. also found, at the penetration rate of $80 \%$ for renewable energy, the water use for the electric power sector could be cut by approximately $50 \%$ in 2050 relative to 2006 [22]. The regional trends in water consumption change with low-carbon technology roadmaps.

- $\mathrm{CO}_{2}$ emission and water withdrawal constraints in the electric sector Webster et al. explored the tradeoffs under the constraints of $\mathrm{CO}_{2}$ emissions and water withdrawals in planning regional electricity generation [23•]. They evaluated different scenarios: a base-case without $\mathrm{CO}_{2}$ emission and water withdrawal limits; $75 \%$ reduction in carbon emissions relative to the base case; $75 \%$ reduction in carbon emissions and $50 \%$ reduction in water withdrawals relative to the base-case. For the assumed fuel prices $(\$ 12.6 / \mathrm{MBtu}$ for natural gas and \$3.5/MBtu for coal), most of the coal capacity is to be replaced by nuclear capacity in order to achieve the $75 \%$ reduction in $\mathrm{CO}_{2}$ emissions, which would increase the regional water withdrawals by $64 \%$, mainly due to additional water use for nuclear generation. Constraining both $\mathrm{CO}_{2}$ emissions and water withdrawals would result in a very different generation mix. Compared with the base-case, the resulting 
NGCC capacity would nearly double and would require dry cooling systems, and nuclear capacity would decrease by $40 \%$ and would require hybrid cooling. For the scenario with both $\mathrm{CO}_{2}$ emission and water-use limits, only $5 \%$ of the total capacity will come from wind generation. The results show that the water-use constraint could also impact the generation mix and the choice of cooling technology.

- Different levels of reductions in energy-system-wide $\mathrm{CO}_{2}$ emissions Cameron et al. evaluated the effects of reducing the energy-system-wide $\mathrm{CO}_{2}$ emissions by $10 \%, 25 \%$, and $50 \%$ on water use for the US electric power sector [24•]. For the $10 \%$ and $25 \%$ reduction scenarios, the electric power sector account for nearly all of the systemwide reductions. Conventional coal plants will be retired gradually. New electricity generation will be supplied by NGCC plants and wind power. In the $50 \%$ reduction scenario, the electric power sector would contribute $75 \%$ of the total system-wide reduction in $\mathrm{CO}_{2}$ emissions. Nuclear power, NGCC-CCS plants, and renewable power (mainly wind) will be three major technologies dominating the future grid of the $50 \%$ reduction scenario. $\mathrm{CO}_{2}$ emission mitigation strategies change with regions. For the $50 \%$ reduction scenario, eastern regions rely heavily on NGCC-CCS and nuclear power, whereas central and western regions rely mainly on wind and solar power plants.

By 2055, the constraint of $\mathrm{CO}_{2}$ emissions would reduce the electric power sector's water withdrawals by $31-46 \%$ in comparison with that of the base-case in 2055, depending on the level of $\mathrm{CO}_{2}$ emission mitigation. However, the trends of water consumption for different mitigation scenarios appear complex. Stringent $\mathrm{CO}_{2}$ emission reductions would increase the penetration of CCS and, in turn, regional water consumption for the electric power sector. By 2055, national water consumption for the $50 \%$ reduction scenario would increase by $42 \%$ compared with that of the base-case in 2055, mainly because of the increased use of closed-loop cooling, nuclear power plants, and NGCC-CCS plants.

Some caveats accompany the existing energy-water assessments. The production of shale gas as a potential major source of US natural gas supply can consume plenty of freshwater from 6,700 to $33,000 \mathrm{~m}^{3}$ per well over its lifecycle, excluding final gas utilization [25]. Water is also needed in the production of chemicals and materials used for $\mathrm{CO}_{2}$ capture. However, existing studies have not carefully addressed the water impacts on a lifecycle basis; existing low-carbon studies do not broaden their outlook for new-generation CCS technologies $[26,27]$; the implementation of CCS may start with partial $\mathrm{CO}_{2}$ capture in response to the EPA's proposed $\mathrm{CO}_{2}$ emission regulations. In addition, flexibly operating $\mathrm{CO}_{2}$ capture at partial load in response to volatile electricity prices could help maintain grid reliability and meet peak demand [28]. However, many studies look into the full $\mathrm{CO}_{2}$ capture (90\%) via CCS for fossil-fuel-fired power plants rather than partial carbon capture; the feasibility of highly aggressive penetration (50-80\% of the fleet) of renewable energy in the future generation fleet needs further technical and economic assessments. Grid-scale energy storage holds the potential to facilitate high penetration of intermittent renewable energy resources into the electric power grid, manage peak demand, and support grid stability [29]. Although pumpedstorage hydroelectricity is the major form of current energy storage for electric power systems [30], battery systems would offer a number of opportunities for grid-scale energy storage, given that lower costs can potentially be obtained [31]. However, there are a number of technical, economic, and regulatory challenges for grid-scale storage applications; without region-specific assessments on resource availability and costs, the recommendation of aggressively employing renewable energy and dry cooling to lower regional water use might misguide stakeholders. Climate change is likely to alter future patterns of regional water availability. However, existing studies mainly focus on the water demand side and barely examine the water demand/supply balance under the varying climate condition; along with water availability vulnerable to climate change, regional energy-water conflicts may vary with regions and seasons over time. However, existing assessments are conducted largely on an annual basis and lack estimates of high temporal resolution; uncertainty in estimating regional water use is ignored widely in existing studies.

\section{Adaptive Approaches to Reinforce Resilience for Low-Carbon Electricity Generation}

Advancing electricity-generation system designs would be helpful to reduce the water use for low-carbon electricity generation. At the plant level, plant efficiency improvements and the use of high-quality coal can remarkably reduce plantlevel water use for new coal-fired plants, subject to the EPA's proposed emission performance standards [20 $]$.

Water availability for thermoelectric power generation could be vulnerable to future climate change [32]. Along with social and economic development, the electric power sector may have a conflict for water use with other sectors. Thus, advanced cooling systems and alternative water resources should be considered in support of low-carbon electricity generation [33], especially when water availability is of concern, including the following.

- Shift from wet cooling to advanced dry or hybrid cooling technologies A new study shows that employing hybrid cooling systems for new coal-fired power plants, subject to the EPA's proposed $\mathrm{CO}_{2}$ emission standards, would 
reduce plant water withdrawals and consumption by $54 \%$ and $58 \%$, respectively, in comparison with the plants using wet cooling towers [20•].

- Water recovery and reuse from power-plant flue gases. A technological assessment shows that $40 \%$ of water vapor from flue gases could be recovered using advanced membrane condensers for reuse within the plant, which could lead to an increase of over $5 \%$ in efficiency [34].

- Reuse of produced water from CCS storage sites or oil and gas fields A large amount of produced water can be extracted from the $\mathrm{CO}_{2}$ storage sites and reused as makeup water for power plants after appropriate treatment [35].

- Use of treated municipal wastewater or brackish water An analysis on the feasibility of using reclaimed water for thermoelectric power plants indicates that sufficient treated wastewater is available within 25 miles of 92 power plants selected in a case study of Texas, representing $61 \%$ of capacity and $50 \%$ of generation in the state [36]. Treated municipal wastewater could be a suitable source of cooling water for thermoelectric power plants to offset some of the freshwater requirements [36]. The major technical challenges for power-plant use are biofouling, inorganic scaling, and corrosion [37].

When assessing the feasibility of alternative water sources, multiple key factors should be taken into account: water quality, water quantity, and source location to determine the water treatment cost, supply capability, and transport and infrastructure costs.

\section{Conclusions}

Recent research indicates that low-carbon electricity generation along with a switch from once-through cooling to wet recirculating cooling in the future would significantly decrease national water withdrawals but may increase national water consumption, especially if CCS and nuclear power are heavily employed in the electric power sector. High penetration of renewable energy into the future generation fleet will markedly lower national water use. Different from national trends, the regional water impacts of low-carbon electricity generation appear complex and vary by location, dependent on the region-specific low-carbon roadmap and the cooling technologies employed. Advanced dry or hybrid cooling systems and alternative water resources can be adopted to support low-carbon energy production for regions where consumptive water use will increase substantially or water supplies will become inadequate.

A changing climate would put significant pressure on the electric power industry's water management, especially in regions facing a water crisis or water scarcity. The availability of water and renewable resources can impact the deployment of low-carbon energy technologies and cooling technologies in operating power generation systems. Thus, an integrated assessment framework that incorporates all the climate, energy, and water components, and examines both the water demand and supply sides, is needed to improve the understanding of the interactions among low-carbon energy production, climate change mitigation, and water-resource planning for a sustainable low-carbon future. Uncertainties in water-use factors and energy projections also need to be incorporated in the framework to offer risk-based assessments for decision making. When a large amount of water is used for the production of low-carbon fuels and materials, the scope of the assessments should be expanded from plant and regional levels to a lifecycle chain. Furthermore, new low-carbon regulatory and policy constraints such as the US EPA's proposed standards and plans for limiting $\mathrm{CO}_{2}$ emissions from the electric power sector need to be considered in the energywater assessments.

\section{Compliance with Ethics Guidelines}

Conflict of Interest Haibo Zhai and Edward S. Rubin declare that they have no conflict of interest.

Human and Animal Rights and Informed Consent This article does not contain any studies with human or animal subjects performed by any of the authors.

\section{References}

Papers of particular interest, published recently, have been highlighted as:

- Of importance

1. Zhai H, Rubin ES, Versteeg PL. Water use at pulverized coal power plants with postcombustion carbon capture and storage. Environ Sci Technol. 2011;45(6):2479-85.

2. Macknick J, Sattler S, Averyt K, Clemmer S, Rogers J. The water implications of generating electricity: water use across the United States based on different electricity pathways through 2050 . Environ Res Lett. 2012;7(4):045803. This study evaluates the national and regional water use of different low-carbon energy pathways and their changing trends over time.

3. Tidwell VC, Malczynski LA, Kobos PH, Klise GT, Shuster E. Potential impacts of electric power production utilizing natural gas, renewables and carbon capture and sequestration on US freshwater resources. Environ Sci Technol. 2013;47(15):8940-7.

4. U.S. Energy Information Administration. Levelized cost and levelized avoided cost of new generation resources in the annual energy outlook 2014. Washington DC: Energy Information Administration; 2014.

5. National Energy Technology Laboratory. Cost and performance baseline for fossil energy plants. Vol. 1: bituminous coal and natural gas to electricity. Revision 2a. Pittsburgh: National Energy Technology Laboratory; 2013. 
6. U.S. Environmental Protection Agency. 2013 proposed carbon pollution standard for new power plants. Available at: http:// www2.epa.gov/carbon-pollution-standards/2013-proposedcarbon-pollution-standard-new-power-plants. Accessed Sept 2014.

7. Zhai H, Rubin ES. Comparative performance and cost assessments of coal- and natural-gas-fired power plants under a $\mathrm{CO}_{2}$ emission performance standard regulation. Energy Fuels. 2013;27(8):4290-301.

8. U.S. Environmental Protection Agency. Clean power plan proposed rule. Available at: http://www2.epa.gov/carbon-pollutionstandards/clean-power-plan-proposed-rule. Accessed Sep 2014.

9. Baker J, Strzepek K, Farmer W, Schlosser CA. Quantifying the impact of renewable energy futures on cooling water use. J Am Water Resour Asssoc. 2014.

10. Zhai H, Rubin ES. Performance and cost of wet and dry cooling systems for pulverized coal power plants with and without carbon capture and storage. Energy Pol. 2010;38(10):5653-60.

11. U.S. Environmental Protection Agency. Water: cooling water intakes. Available at: http://water.epa.gov/lawsregs/lawsguidance/ cwa/316b/. Accessed Sep 2014.

12. Macknick J, Newmark R, Heath G, Hallett KC. Operational water consumption and withdrawal factors for electricity generating technologies: a review of existing literature. Environ Res Lett. 2012;7(4):045802. This study well summarizes water use intensities and their ranges for a broad range of electric power generation systems and cooling technologies.

13. Chandel MK, Pratson LF, Jackson RB. The potential impacts of climate-change policy on freshwater use in thermoelectric power generation. Energy Pol. 2011;39(10):6234-42. This study evaluates water impacts of different low-carbon scenarios and regional variability in water use.

14. Averyt K, Macknick J, Rogers J, Madden N, Fisher J, Meldrum J, et al. Water use for electricity in the United States: an analysis of reported and calculated water use information for 2008. Environ Res Lett. 2013;8(1):015001.

15. U.S. Energy Information Administration. The national energy modeling system: an overview 2009. DOE/EIA-0581(2009). Washington, DC: Department of Energy; 2009.

16. Clemmer S, Rogers J, Sattler S, Macknick J, Mai T. Modeling lowcarbon US electricity futures to explore impacts on national and regional water use. Environ Res Lett. 2013;8(1):015004. This study comparatively quantifies the effects of different low-carbon energy pathways on the regional and national water use.

17. Davies EGR, Kyle P, Edmonds JA. An integrated assessment of global and regional water demands for electricity generation to 2095. Adv Water Resour. 2013;52:296-313.

18. Kyle P, Davies EGR, Dooley JJ, Smith SJ, Clarke LE, Edmonds JA, et al. Influence of climate change mitigation technology on global demands of water for electricity generation. Int $\mathrm{J}$ Greenh Gas Control. 2013;13:112-23.

19. U.S. Environmental Protection Agency. U.S. national MARKAL database: database documentation. EPA-600/R-06/057. Washington, DC: Environmental Protection Agency; 2006.

20. Talati S, Zhai H, Morgan MG. Water impacts of $\mathrm{CO}_{2}$ emission performance standards for fossil fuel-fired power plants. Environ Sci Technol. 2014;48(20):11769-76. This study systematically quantifies the water use impacts of new source performance standards for limiting CO2 emissions from coal and natural gas fired power plants.
21. Tidwell VC, Kobos PH, Malczynski LA, Klise G, Castillo CR. Exploring the water-thermoelectric power Nexus. J Water Resour Plan Manag. 2011;138(5):491-501. This study identifies possible regions that may face water challenges for different energy production roadmaps.

22. Arent D, Pless J, Mai T, Wiser R, Hand M, Baldwin S, et al. Implications of high renewable electricity penetration in the US for water use, greenhouse gas emissions, land-use, and materials supply. Appl Energy. 2014;123:368-77.

23. Webster M, Donohoo P, Palmintier B. Water-CO2 trade-offs in electricity generation planning. Nat Clim Change. 2013;3(12): 1029-32. This study evaluates the effects on a region's electricity grid mix and cooling technology share from limiting CO2 emissions and water withdrawals.

24. Cameron C, Yelverton W, Dodder R, West JJ. Strategic responses to $\mathrm{CO} 2$ emission reduction targets drive shift in US electric sector water use. Energy Strateg Rev. 2014;4:16-27. This study evaluates the effects on water withdrawals and consumption from three levels of reductions in energy system-wide $\mathrm{CO} 2$ emissions.

25. Jiang M, Hendrickson CT, VanBriesen JM. Life cycle water consumption and wastewater generation impacts of a Marcellus shale gas well. Environ Sci Technol. 2014;48(3):1911-20.

26. Rubin ES, Mantripragada H, Marks A, Versteeg P, Kitchin J. The outlook for improved carbon capture technology. Prog Energy Combust Sci. 2012;38(5):630-71.

27. Zhai H, Rubin ES. Techno-economic assessment of polymer membrane systems for postcombustion carbon capture at coal-fired power plants. Environ Sci Technol. 2013;47(6):3006-14.

28. Cohen SM, Rochelle GT, Webber ME. Optimizing postcombustion $\mathrm{CO}_{2}$ capture in response to volatile electricity prices. Int J Greenh Gas Control. 2012;8:180-95.

29. Castillo A, Gayme DF. Grid-scale energy storage applications in renewable energy integration: a survey. Energy Convers Manag. 2014;87:885-94.

30. Electric Power Research Institute. Bulk energy storage impact and value analysis. Product ID: 1024288; 2012.

31. Dunn B, Kamath H, Tarascon J-M. Electrical energy storage for the grid: a battery of choices. Science. 2011;334(6058):928-35.

32. Van Vliet MTH, Yearsley JR, Ludwig F, Vögele S, Lettenmaier DP, Kabat P. Vulnerability of US and European electricity supply to climate change. Nat Clim Chang. 2012;2(9):676-81.

33. Tidwell VC, Macknick J, Zemlick K, Sanchez J, Woldeyesus T. Transitioning to zero freshwater withdrawal in the US for thermoelectric generation. Appl Energy. 2014;131:508-16.

34. Wang D, Bao A, Kunc W, Liss W. Coal power plant flue gas waste heat and water recovery. Appl Energy. 2012;91(1):341-8.

35. Roach JD, Heath JE, Kobos PH, Klise GT. System-level benefits of extracting and treating saline water from geologic formations during national-scale carbon capture and storage. Int J Greenh Gas Control. 2014;25:186-97.

36. Stillwell AS, Webber ME. Geographic, technologic, and economic analysis of using reclaimed water for thermoelectric power plant cooling. Environ Sci Technol. 2014;48(8):4588-95.

37. Heng L, Chien S-H, Hsieh M-K, Dzombak DA, Vidic RD. Escalating water demand for energy production and the potential for use of treated municipal wastewater. Environ Sci Technol. 2011;45(10):4195-200. 